\title{
STUDI KARAKTERISTIKPROSES PIROLISIS DAN ARANG DARI BRIKET SERBUK KAYU DENGAN VARIASI LAJU PEMANASAN MENGGUNAKAN METODE PIROLISIS SINGLE ROCKET STOVE
}

\author{
Endah Ayuningtyas ${ }^{1)}$ M.Noviansyah Aridito ${ }^{2)}$ \\ ${ }^{1)}$ Teknik Lingkungan Institut Teknologi Yogyakarta \\ ${ }^{2)}$ Teknik Lingkungan Universitas Proklamasi 45 \\ Alamat email : endaha25@ity.ac.id
}

\begin{abstract}
ABSTRAK
Limbah serbuk kayu memiliki posisi strategis yakni untuk mengurangi volume limbah biomassa dan menjadi sumber energi baru terbarukan. Hal ini membuat permintaan terhadap briket arang serbuk kayu cukup baik di pasar global. Namun, kendala produksi dari briket kayu yakni pada proses produksi yang relatif lama dengan oven lebih dari 8 jam, menghasilkan asap dan abu sehingga terkadang menghasilkan reject dan gangguan lingkungan. Teknologi pirolisis dengan metode Single Retort Rocket Stove menjadi salah satu solusinya dimana memiliki desain pemanasan di bagian tengah sehingga lebih merata dari bawah ke atas dan lebih cepat dengan memanfaatkan kembali gas pirolisisnya sebagai bahan bakar sehingga dapat mereduksi polusi asap dan efisiensi energi.

Penelitian ini bertujuan untuk mengetahui karakteristik proses dan produk dari pirolisis briket serbuk kayu dengan Single Retort Rocket Stove dimana dilakukan variasi laju pemanasan. Hasil penelitian menunjukkan bahwa proses pirolisis menggunakan Retort Pirolisis Rocket Stove dapat mempirolisis briket arang limbah serbuk kayu dengan menghasilkan gas pirolisis mempan bakar yang dapat digunakan untuk pemanasan tanpa menghasilkan abu. Proses berlangsung selama 90 menit dan menghasilkan gas pirolisis mempan bakar paling cepat pada menit ke-10 dengan laju pemanasan paling tinggi $\left(15^{\circ} \mathrm{C} / \mathrm{m}\right)$.

Karakteristik produk berupa briket arang menunjukkan nilai kalor antara 6913,58- 7039,83 kkal/kg; kadar karbon terikat antara 80,33 - 80,89 \%, Kadar air antara 6,59 - 7,02\%, kadar zat terbang antara 11,92-12,54\% dan kadar abu 6,20$6,27 \%$. Terdapat kecenderungan pada pengaruh laju pemanasan pada proses dan produk dimana laju panas yang tinggi cenderung menghasilkan gas pirolisis yang lebih cepat dan briket arang serbuk kayu dengan nilai kalor, kadar karbon, kadar abu dan kadar air yang lebih rendah.Keseluruhan sampel memenuhi standar briket arang Jepang, Amerika dan Inggris untuk nilai kalor, kadar karbon terikat, kadar zat terbang namun belum memenuhi untuk kadar abu dan kadar air.
\end{abstract}

Kata kunci: Briket Arang, Serbuk Kayu, Pirolisis, Single Retort, Rocket Stove 


\title{
CHARACTERISTIC STUDY OF PYROLYSIS PROCESS AND CHARCOAL FROM SAWDUST BRIQUETTE WITH HEATING RATE VARIATIONS USING SINGLE ROCKET STOVE PYROLYSIS METHOD
}

\begin{abstract}
Sawdust has a strategic position to reduce the volume of biomass waste and become a new renewable energy source. This makes the demand for sawdust charcoal briquettes quite good in the global market. However, the constraints of production of sawdust charcoal briquettes are the relatively long production process more than 8 hours, resulting in smoke and ash so that it sometimes produces rejects and environmental disturbances. Pyrolysis technology with the Single Retort Rocket Stove method is one solution. Rocket Stove Pyrolizer has a heating system design in the middle of the retort. The Heat distributed from the bottom up and faster than conventional pyrolysis. It's also allow to reusing pyrolysis gas as fuel. This technology can reduce smoke pollution and improve energy efficiency from the recycle pyrolysis gas as a resource of energy.

This study aims to determine the process and product characteristics of pyrolysis of sawdust briquettes with Single Retort Rocket Stove where variations in heating rates are carried out. The results showed that the pyrolysis process using Pyrolysis Rocket Stove Retort able to pyrolyze Sawdust briquettes into charcoal briquettes and producing combustible pyrolysis. Pyrolysis gas which can be used for heating. This technology also easy to handle without producing ash. The pyrolysis process about 90 minutes and produces pyrolysis gas that burns the fastest in the 10th minute with the highest rate of expansion $\left(15^{\circ} \mathrm{C} / \mathrm{m}\right)$.

Product characteristics in the form of charcoal briquettes show a heating value (Gross heating value) between 6913.58 - $7039.83 \mathrm{kcal} / \mathrm{kg}$; Fixed carbon content between 80.33 - 80.89\%, moisture content between 6.59- 7.02\%, Volatile Matter between $11.92-12.54 \%$ and ash content between $6.20-6.27 \%$. There is a tendency to influence the rate of heating in processes and products where high heat rates tend to produce faster pyrolysis gas and wood powder charcoal briquettes with lower heating values, carbon content, ash content and water content. All samples met the standards of Japanese, American and English charcoal briquettes for calorific value, bound carbon content, levels of flying substances but did not meet the ash content and moisture content.
\end{abstract}

Keywords: Charcoal Briquettes, Sawdust, Pyrolysis, Single Retort, Rocket Stove

\section{A. PENDAHULUAN}

Briket dari limbah serbuk kayu saat ini cukup berkembang di Indonesia, hal ini terbukti dengan adanya ekspor briket serbuk kayu yang semakin meningkat. Briket serbuk kayu menjadi isu yang menarik karena memiliki dua manfaat sekaligus yakni 1) mengatasi masalah limbah biomassa dari 
produksi kayu 2) mengatasi masalah pemenuhan energi baru terbarukan berbasis limbah biomassa (Waste to Energy). Hal ini sangat mendukung dengan kebijakan pemerintah berkait dengan Kebijakan Energi Nasional melalui Peraturan Pemerintah Nomor 79 Tahun 2014,Permen ESDM No 12 Tahun 2017 Tentang Pemanfaatan Sumber Daya Energi untuk Penyediaan Tenaga Listrik dan UU RI tentang pengelolaan sampah No.32 Tahun 2009. Pada level Global, briket arang serbuk kayu mendukung terwujudnya Program PBB yakni Sustainable Development Goals (SDG's) tentang energi dan sampah/limbah.

Indonesia merupakan negara tropis yang kaya akan sumber biomassa terutama kayu-kayuan. Hal ini tentu mendukung berkembangnya produksi briket arang dari serbuk kayu. Namun, tantangan yang dihadapi produsen briket serbuk kayu salah satunya saat proses pengarangan briket serbuk kayu yang telah di cetak menggunakan mesin screw ekstruder. Proses pengarangan konvensional menggunakan oven pemanasan memerlukan energi yang cukup besar, belum lagi masalah kegagalan proses akibat terlalu panas atau terlalu tinggi laju pemanasan sehingga briket serbuk kayu menjadi retak, hancur dan bahkan menjadi abu. Hal ini menyebabkan adanya residu proses sehingga menurunkan keuntungan ekonomi produksi briket arang serbuk kayu.
Teknologi pengarangan banyak dikembangkan melalui proses pirolisis. Pirolisis biomassa yakni proses pemecahan senyawa biomassa menggunakan panas tanpa adanya kehadiran oksigen yang menghasilkan arang, cairan/asap cair/biooil dan gas. Teknologi pirolisis memiliki beberapa jenis untuk reactor fixed bed yakni pemanasan dari dalam reactor dengan membakar bahan bakunya dimana diberikan sedikit sekali aliran udara dan pemanasan dari luar dimana bahan baku dimasukkan dalam reactor/retort tertutup lalu dipanaskan hingga menjadi arang. Teknologi yang digunakan dalam penelitian ini yakni Teknologi Pirolisis Single Retort dengan Metode Pemanasan Rocket Stove. Teknologi ini juga memanfaatkan gas pirolisisnya kembali sehingga meminimalisir asap dan efisien dalam konsumsi energi. Teknologi ini menggunakan retort khusus dengan pemanasan bagian tengah berbentuk silinder L sehingga panas lebih merata dengan metode rocket stove.

Penelitian ini fokus pada karakteristik bioarang briket serbuk kayu dengan metode pirolisis single retort rocket stove dengan laju pemanasan $\quad 5,63^{\circ} \mathrm{C} /$ menit, $\quad 8,18$ ${ }^{\circ} \mathrm{C} /$ menit dan $15^{\circ} \mathrm{C} /$ menit. Karakteristik yang di uji yakni nilai kalor, karbon terikat, kadar abu, kadar air dan kadar zat terbang yang kemudian dikomparasi dengan 
standar briket serbuk kayu ekspor di Jepang, Amerika dan Inggris

\section{B. TINJAUAN PUSTAKA}

Penelitian terkait briket serbuk kayu telah dilakukan oleh beberapa peneliti yakni Penelitian tentang pirolisis briket serbuk kayu dilakukan oleh Aridito, (2019) menggunakan Pirolisis Twin Retort Rocket Stoveberkaitan pengaruh laju pemanasan dan laju hisap gas pirolisis pada briket serbuk kayu dimana terdapat kecenderungan pengaruh laju hisap gas dan laju pemanasan terhadap karakteristik briket arang.

Penelitian tentang komposisi campuran briket serbuk kayu juga dilakakukan oleh beberapa peneliti. Mansyur, (2018) menggunakan Pirolisis Single Retort Rocket Stove. melakukan karakterisasi briket arang dari campuran serbuk gergaji kayu dengan variasi komposisi dan suhu puncak dimana terdapat pengaruh komposisi dan suhu puncak terhadap karakteristik briket. Pengaruh karakteristik campuran birket arang juga diteliti oleh Basriyanta (2007) dengan campuran ampas jarak pagar. Begitu pula penelitian tentang campuran serbuk kayu dan tempurung kelapa pada briket yang dilakuka oleh Saleh (2017), dimana penambahan tempurung kelapa mampu meningkatkan kualotas briket serbuk gergaji kayu dimana tertinggi pada campuran serbuk kayu
: tempurung kelapa 40\%:60\% yakni 7386,48 kal/gram.

Penelitian lain yang mencampurkan serbuk kayu dengan cangkang kelapa sawit dilakukan oleh Wijayanti, (2009). Hasil penelitian menunjukkan penambahan arang cangkang kelapa sawit dengan serbuk kayu berpengaruh pada nilai kalor dengan nilai kalor tertinggi pada campuran serbuk kayu dan arang cangkang sawit 50\% sebesar 6117,67 kal/gram

$$
\text { Penelitian tentang }
$$

karakteristik termal dilakukan oleh Yunus (2015) yakni karakteristik thermal briket limbah serbuk kayu sengon dengan variasi tekanan sedangkan penelitian Patabang (2013) yakni karakteristik termal briket arang serbuk gergaji kayu meranti dengan hasil nilai kalor $5731,1 \mathrm{kal} / \mathrm{g}$ moisture $1,72 \%$, ash $3,97 \%$, fixed carbon $65,90 \%$, dan volatile matter $29,19 \%$ dan memenuhi syarat sebagai bahan bakar alternative

Patandung dan Silabun (2017) juga melakukan penelitian tentang karakteristik penyalaan briket limbah serbuk arang tempurung kelapa dengan bahan pemantik abu kelapa (cocodust) sedangkan Saputro dkk (2012) karakteristik briket limbah pengolahan kayu sengon dengan metode cetak panas.

Perbedaan dan kebaruan dari penelitian ini yakni melakukan studi karakteristik proses dan produk 
briket limbah serbuk kayu pada proses pirolisis dengan metode single retort rocket stove dengan variasi laju pemanasan sehingga diperoleh informasi tentang karakteristik proses dan produk briket arang untuk dikomparasi dengan standar briket arang internasional

\section{METODE PENELITIAN}

Pirolisis dilakukan dengan menggunakan burner minyak plastik sebagai pemanasan awal (initial heating). Burner Pirolisis digunakan hingga proses pirolisis mencapai suhu $\pm 450^{\circ} \mathrm{C}$ dan digunakan untuk menahan pada suhu tersebut. Pengaturan laju pemanasan menggunakan katup pada burner yang dibuka pada 1/4, 1/2 dan dibuka penuh. Bahan bakar minyak yang digunakan menggunakan jenis minyak pirolisis plastik dari plastik HDPE dan LDPE dan oli bekas. Pada penelitian ini digunakan oli bekas.

Burner yang digunakan menggunakan kompresor dengan tekanan minimal 4 Bar. Tekanan dari kompresor untuk mempermudah pengabutan minyak plastic yang akan dibakar. Tekanan kompresor pada burner rata-rata sebesar antara 5-6 Bar. Tahap penyalaan minyak plastik dialirkan dengan membuka katup pada burner agar minyak mengalir ke ruang bakar. Oli di bakar terlebih dahulu hingga menyala lalu kompresor dinyalakan dan katup udara bertekanan dari kompresor dibuka dan dialirkan ke ruang bakar.
Oli akan terbakar dengan tekanan dari kompresor. Katup pada tekanan kompresor dan aliran dapat dikontrol untuk menentukan variasi laju pemanansan. Proses pirolisis menggunakan bahan bakar dilakukan masing-masing selama 90 menit.

Bahan baku dimasukkan dalam retort hingga terisi $3 / 4$ retort. Briket serbuk kayu sawdust memiliki bentuk segi-6 dengan panjang $40 \mathrm{~cm}$ sehingga dapat disusun di dalam retort. Tiap briket biomassa memiliki massa sekitar $1 \mathrm{~kg}$ (1000 gram). Pirolisis Rocket menggunakan pengembangan dari model rocket stove. Pirolisis recket berbentuk seperti retort tabung dengan diameter 20 inch. Pada bagian tengah retort diberikan ruang bakar dan aliran udara dengan silinder diameter 6 inch.

Pada bagian samping dihubungkan dengan pipa 2 inch untuk outlet gas dari ruang pirolisis yang dihubungkan dengan saluran pipa menuju ruang bakar. Bahan baku dimasukkan diruang pirolisis dan Proses Pirolisis dilakukan selama 1,5 jam.

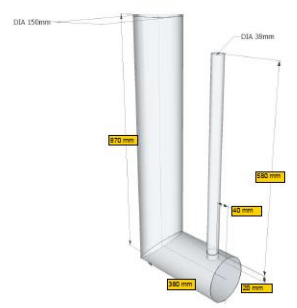

Gambar 1. Bagian Rocket Stove dengan Pipa Gas Pirolisis 


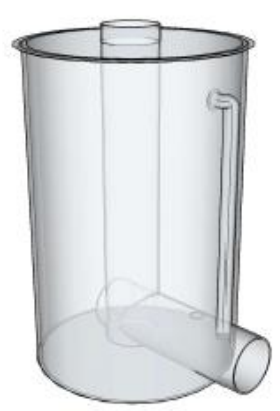

Gambar. 2. Alat Pirolisis Single Retort dengan Pemanasan Rocket Stove dalam penelitian

\section{HASIL DAN PEMBAHASAN}

Proses dan data pirolisis briket serbuk kayu (sawdust) dilakukan dengan menggunakan sample briket sawdust dengan massa sekitar 1000 gram untuk masngmasing sampel diberi tanda lilitan kawat. Pirolisis dilakukan menggunakan variasi laju pemanasan. Laju pemanasan diperoleh dari variasi bukaan katup hingga mencapai suhu $450^{\circ} \mathrm{C}$, terlihat pada Tabel 1 .

Laju pemanasan yang diperoleh yakni $5,63{ }^{\circ} \mathrm{C} / \mathrm{m} ; 8,18$ ${ }^{\circ} \mathrm{C} / \mathrm{m}$; dan $15{ }^{\circ} \mathrm{C} / \mathrm{m}$ hingga mencapai suhu $450{ }^{\circ} \mathrm{C}$ dan ditahan selama sekitar total waktu 1,5 jam (90 menit). Berdasarkan hasil tersebut diperoleh data profil suhu proses pirolisis, penyusutan massa bahan baku dan arang briket limbah serbuk kayu untuk dilakukan uji laboratorium berkaitan dengan Nilai Kalor (Gross Heating Value) dan Proksimate Analisis untuk mengetahui kualitas briket arang dan komparasi kualitas briket arang di pasaran Global.

Tabel 1. Proses Pirolisis Briket Serbuk Kayu dengan Pirolisis Single Rocket Stove

\begin{tabular}{lllll}
\hline & & Sampel A & Sampel B & Sampel C \\
\hline 1. & Bukaan Katup Burner & $1 / 4$ & $1 / 2$ & 1 \\
2. & Laju Pemanasan & $5,63{ }^{\circ} \mathrm{C} / \mathrm{m}$ & $8,18{ }^{\circ} \mathrm{C} / \mathrm{m}$ & $15^{\circ} \mathrm{C} / \mathrm{m}$ \\
3. & Gas Pirolisis mempan bakar & Menit ke- & Menit ke & Menit ke 10 \\
& $\begin{array}{l}\text { untuk proses terbentuk pada } \\
\text { menit }\end{array}$ & 18 & 14 & \\
$\begin{array}{l}\text { 4erbentuk Abu } \\
\text { 5 }\end{array}$ & Lama Proses & Tidak & Tidak & Tidak \\
\hline
\end{tabular}

Berdasarkan hasil pada pengambilan data diperoleh informasi yakni sampel A dilakukan proses pirolisis dengan pemanasan dari burner dimana katup burner dengan nyala api di buka $1 / 4$ hingga suhu bertahan di $450{ }^{\circ} \mathrm{C}$ sehingga diperoleh rata-rata laju pemanasan $5,63{ }^{\circ} \mathrm{C} / \mathrm{m}$. Gas pirolisis yang mempan bakar pertama kali muncul pada menit ke 18 sehingga dapat membantu proses pirolisis sebagai 
tambahan sumber panas. Sampel B diatur bukaan katup $1 / 2$ dan sampel $\mathrm{C}$ dibuka penuh sehingga diperoleh kecenderungan semakin besar pembukaan katup, laju pemanasan semakin tinggi dan pembentukan gas pirolisis mempan bakar relatif semakin cepat.

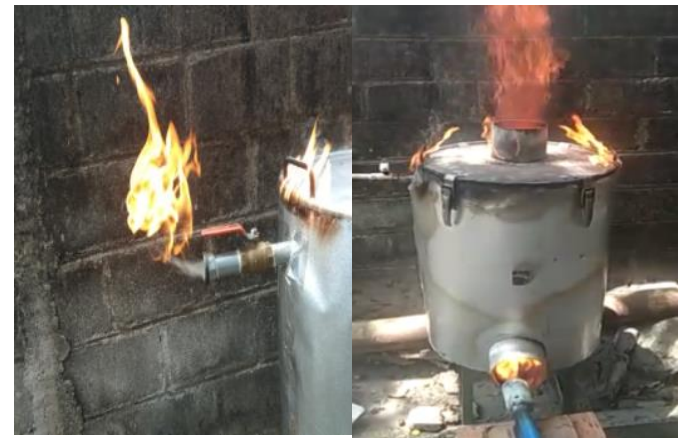

Gambar 3. Gas Pirolisis dari Briket Serbuk Kayu untuk Sumber Pemanasan.

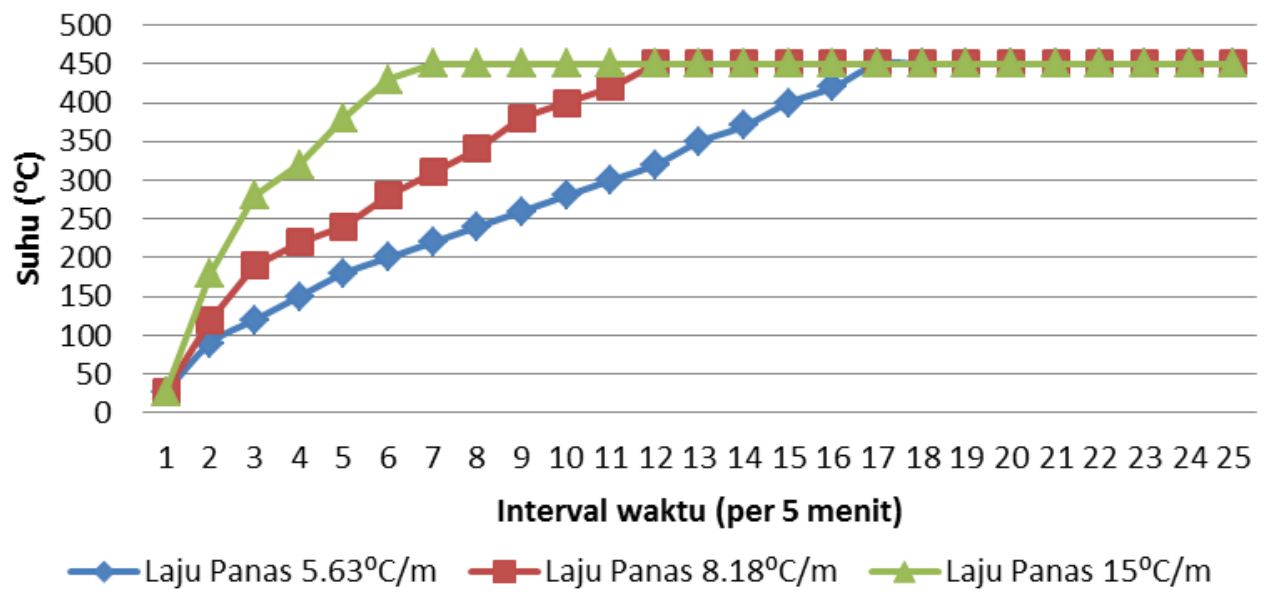

Gambar 4. Profil suhu pada proses pirolisis dengan variasi laju pemanasan

Profil suhu pirolisis ditunjukkan Gambar 4. Sampel A dengan laju panas terendah yakni $5,63{ }^{\circ} \mathrm{C} / \mathrm{m}$ menunjukkan kenaikan suhu hingga mencapai $450^{\circ} \mathrm{C}$ yang lebih lambat dan landai dari kemiringan sudutnya sedangkan sampel $\mathrm{C}$ dengan laju pemanasan tertinggi yakni $15 \quad{ }^{\circ} \mathrm{C} / \mathrm{m}$ menunjukkan kenaikan suhu yang cepat dengan kemiringan grafik yang lebih tajam/ sudut lebih besar. Hal ini juga berdampak pada holding time pada suhu puncak $450{ }^{\circ} \mathrm{C}$ dimana laju pemanasan yang lebih tinggi memiliki holding time pada suhu puncak lebih lama. Gas Pirolisis yang mempan bakar juga menunjukkan perbedaan pada awal kemunculannya dimana pada laju pemanasan yang lebih tinggi gas pirolisis terbentuk lebih cepat. Proses pirolisis dilakukan hingga 1,5 jam lalu dihentikan dengan mematikan burner dan menutup lubang gas pirolisis lalu di biarkan dingin kemudian dibuka dan di ambil 3 sampel briket arang (diberi tanda dengan lilitan kawat). 
Briket arang yang telah selesai proses pirolisis dilakukan uji laboratorium di Laboratorium Perpindahan Massa dan Panas PAU UGM, pada pengujian karakteristik nilai kalor (Gross heating value),
Kadar Karbojn Terikat (Fixed Carbon), Kadar Abu (Ash Content), Kadar Zat terbang (Volatile Matter) dan Kadar Air (Moisture Content) . Tabel 2 menunjukan Hasil Uji Laboratorium yang telah dilakukan.

Tabel 2. Hasil Uji Nilai Kalor (Gross Heating Value) dan Proksimate Analisis Briket Arang Sawdust

\begin{tabular}{|c|c|c|c|c|}
\hline No & Uraian & $\begin{array}{c}\text { Sampel A } \\
10 \mathrm{C}\end{array}$ & $\begin{array}{c}\text { Sampel B } \\
15 \mathrm{C}\end{array}$ & $\begin{array}{c}\text { Sampel C } \\
20 \mathrm{C}\end{array}$ \\
\hline \multirow[t]{3}{*}{1} & GHV (kcal/kg) & 7044.09 & 6956.05 & 6901.86 \\
\hline & & 7035.56 & 7009.21 & 6925.29 \\
\hline & Rata-rata & 7039.83 & 6982.63 & 6913.58 \\
\hline \multirow[t]{3}{*}{2} & Fixed & 80.93 & 80.57 & 80.26 \\
\hline & Carbon(\%) & 80.85 & 80.47 & 80.39 \\
\hline & Rata-rata & 80.89 & 80.52 & 80.33 \\
\hline \multirow[t]{3}{*}{3} & AshContent $(\%)$ & 6.25 & 6.23 & 6.25 \\
\hline & & 6.28 & 6.31 & 6.15 \\
\hline & Rata-rata & 6.27 & 6.27 & 6.20 \\
\hline \multirow[t]{3}{*}{4} & Volatile & 11.91 & 12.21 & 12.53 \\
\hline & Matter(\%) & 11.92 & 12.16 & 12.54 \\
\hline & Rata-rata & 11.92 & 12.19 & 12.54 \\
\hline \multirow[t]{3}{*}{5} & Moisture & 6.94 & 6.96 & 6.55 \\
\hline & Content $(\%)$ & 7.09 & 6.81 & 6.62 \\
\hline & Rata-rata & 7.02 & 6.89 & 6.59 \\
\hline
\end{tabular}

Berdasarkan hasil pengujian laboratorium seperti pada Tabel 2, maka diperoleh beberapa informasi berkaitan dengan karakteristik fisikkimia briket arang limbah serbuk kayu dengan proses pirolisis single retort rocket. Data kemudian dianalisis dan diperoleh beberapa informasi berkaitan dengan karakteristik fisik-kimia briket arang berdasarkan variasi laju pemanasan.

Berdasarkan data tersebut terlihat seperti Gambar 5, sampel A dengan laju pemanasan $5,63{ }^{\circ} \mathrm{C} / \mathrm{m}$ memiliki nilai kalor yang lebih tinggi yakni 7039,83 $\mathrm{kkal} / \mathrm{kg}$ dibanding sampel B dengan laju pemanasan $8,18^{\circ} \mathrm{C} / \mathrm{m}$ yakni $6982,63 \mathrm{kkal} / \mathrm{kg}$ dan Sampel C dengan laju pemanasan 15 ${ }^{\circ} \mathrm{C} / \mathrm{m}$ yakni $6913,58 \mathrm{kkal} / \mathrm{kg}$. Hal ini menunjukkan kecenderungan laju pemanasan semakin tinggi maka nilai kalor cenderung semakin rendah.

Kadar karbon terikat terlihat seperti Gambar 6, memiliki 
kecenderungan laju pemanasan semakin tinggi maka kadar karbon terikat cenderung semakin rendah. Hal ini terlihat dari sampel A dengan laju pemanasan $5,63{ }^{\circ} \mathrm{C} / \mathrm{m}$ memiliki kadar karbon terikat yang lebih tinggi yakni $80,89 \%$ dibanding sampel B dengan laju pemanasan $8,18^{\circ} \mathrm{C} / \mathrm{m}$ yakni $80,52 \%$ dan sampel $\mathrm{C}$ dengan laju pemanasan $15{ }^{\circ} \mathrm{C} / \mathrm{m}$ yakni $80,33 \%$. Hal ini menunjukkan kecenderungan

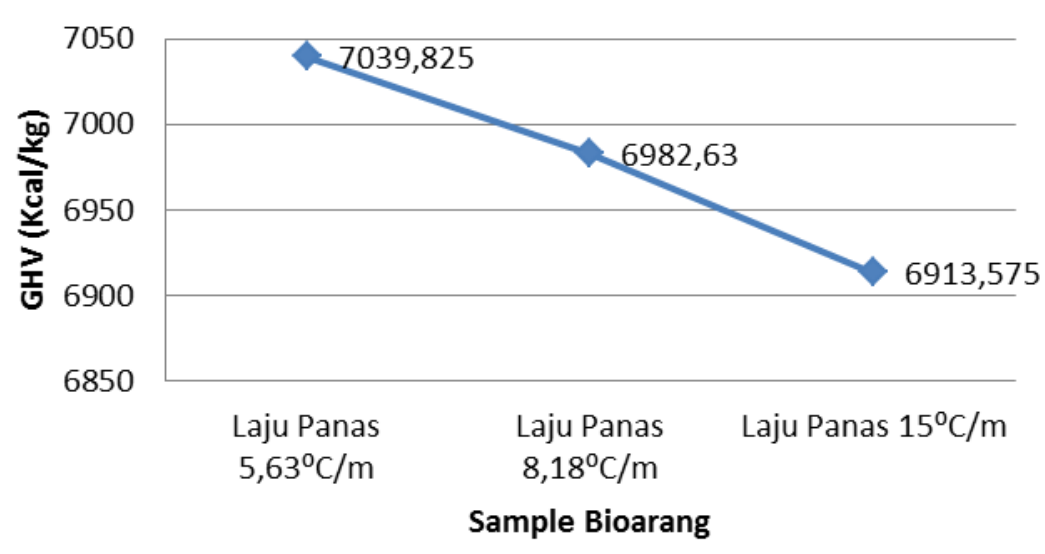

Gambar 5. Hubungan Nilai Kalor Briket Arang Sawdust dengan Variasi Laju Pemanasan pada Pirolisis Single Retort Rocket Stove

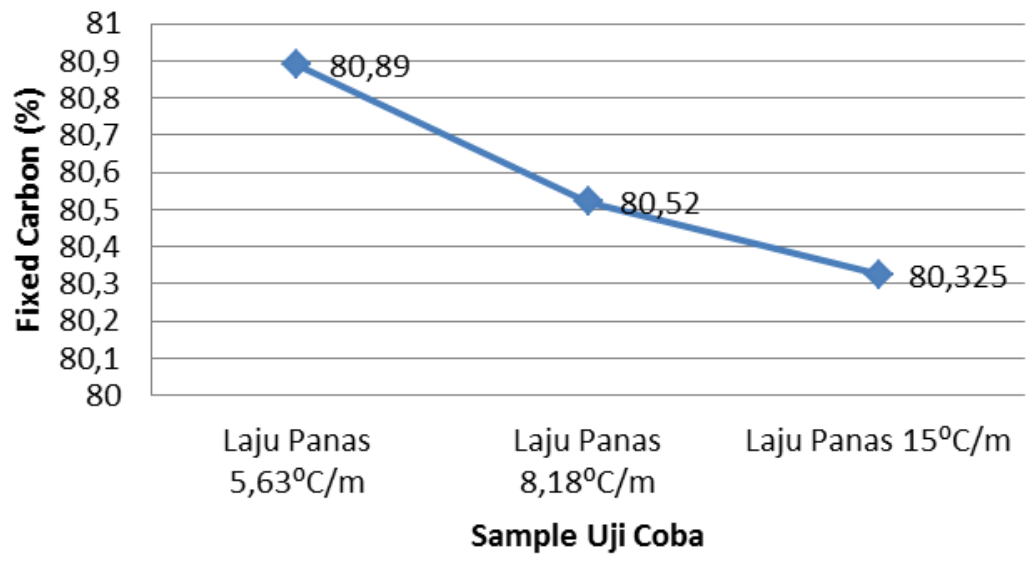

Gambar 6. Hubungan Kadar Karbon Terikat dari Briket Arang Sawdust dengan Variasi Laju Pemanasan pada Pirolisis Single Retort Rocket Stove 


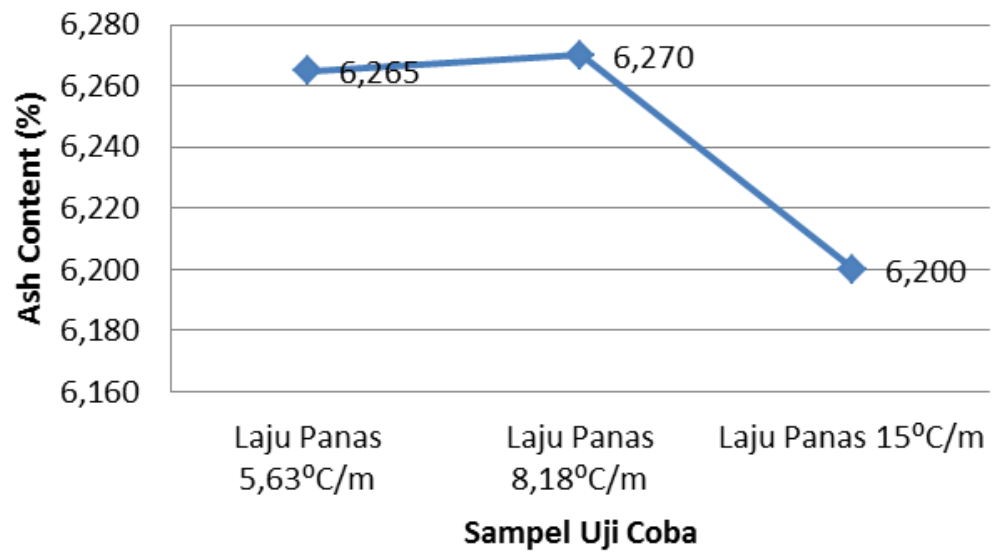

Gambar 7. Hubungan Kadar Abu dari Briket Arang Sawdust dengan Variasi Laju Pemanasan pada Pirolisis Single Retort Rocket Stove

Nilai kadar abu seperti pada Gambar7 menunjukkan kecenderungan laju pemanasan semakin tinggi maka kadar karbon terikat cenderung semakin rendah. Sampel A dengan laju pemanasan $5,63{ }^{\circ} \mathrm{C} / \mathrm{m}$ memiliki kadar karbon terikat yang lebih tinggi yakni $80,89 \%$ dibanding sampel B dengan laju pemanasan $8,18{ }^{\circ} \mathrm{C} / \mathrm{m}$ yakni $80,52 \%$ dan sampel $\mathrm{C}$ dengan laju pemanasan $15{ }^{\circ} \mathrm{C} / \mathrm{m}$ yakni $80,33 \%$.

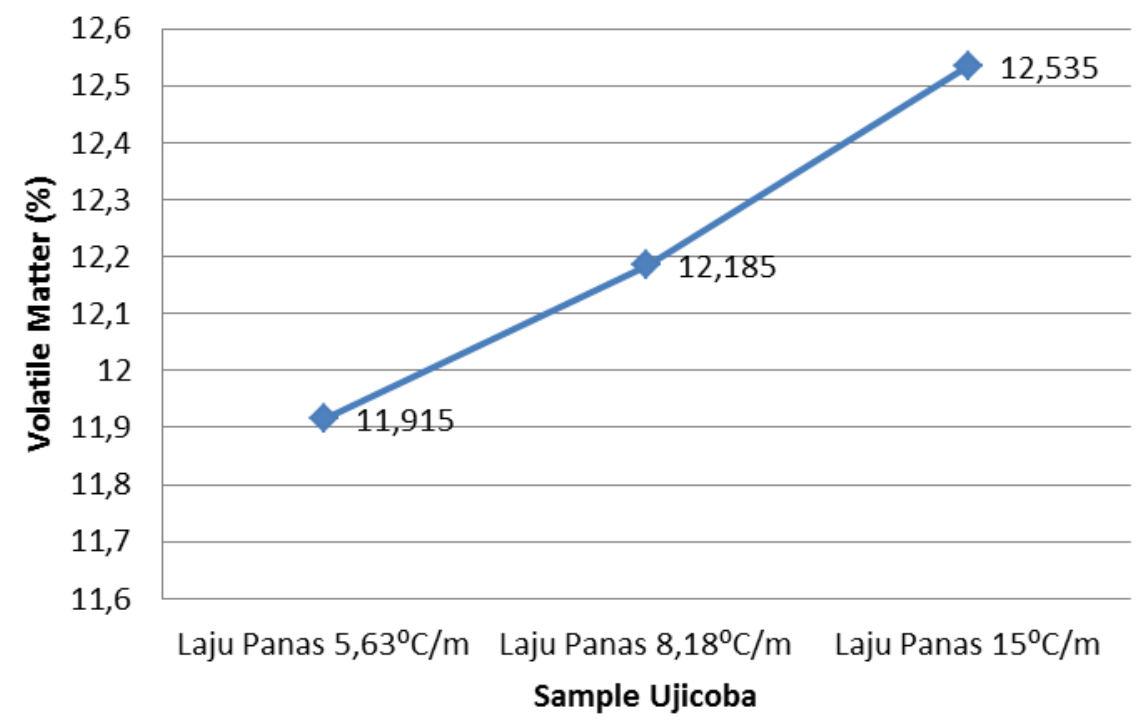

Gambar 8. Hubungan Kadar Zat Terbang dari Briket Arang Sawdust dengan Variasi Laju Pemanasan pada Pirolisis Single Retort Rocket Stove

Berdasarkan Gambar 8, kadar zat terbang (volatile matter) sampel
A memiliki kadar zat terbang yang lebih rendah yakni 11,915\% 
dibanding sampel B yakni 12,185\% dan sampel $\mathrm{C}$ dengan laju pemanasan yakni $12,535 \%$. Hal ini menunjukkan kecenderungan laju pemanasan semakin tinggi maka kadar zat terbang cenderung semakin tinggi.

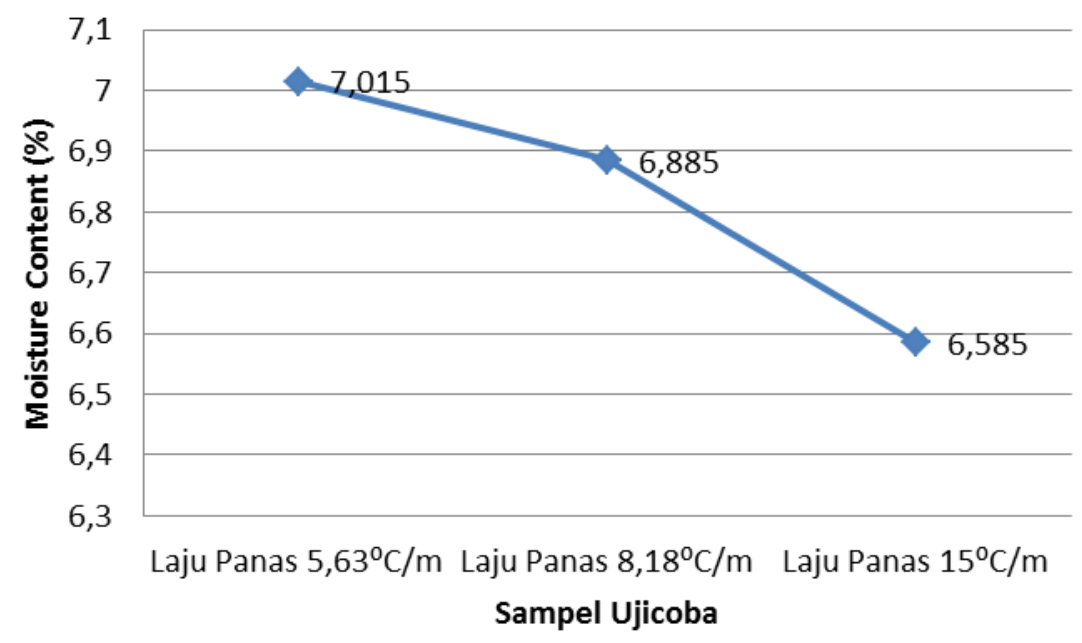

Gambar 9. Hubungan Kadar Air dari Briket Arang Sawdust dengan Variasi Laju Pemanasan pada Pirolisis Single Retort Rocket Stove

Kadar air (Gambar 9) dari proses pirolisis ini juga menunjukkan kecenderungan laju pemanasan semakin tinggi maka kadar air cenderung semakin rendah seperti pada Gambar 10. Hal ini menunjukkan bahwa air menguap lebih cepat pada laju pemanasan yang lebih tinggi dimana memiliki holding time yang lebih lama. Hasil uji laboratorium kemudian dikomparasi dengan standar briket arang Jepang, Amerika dan Inggris untuk mengetahui kualitas dari produk briket arang. Komparasi ditunjukkan pada Tabel 3 .

Tabel 3. Standar Briket Arang untuk Jepang, Amerika, Inggris dan Indonesia

\begin{tabular}{lcccccc}
\hline \multicolumn{1}{c}{ Sifat } & Jepang & Amerika & Inggris & $\begin{array}{c}\text { Sampel } \\
\text { A }\end{array}$ & $\begin{array}{c}\text { Sampel } \\
\text { B }\end{array}$ & $\begin{array}{c}\text { Sampel } \\
\text { C }\end{array}$ \\
\hline Kadar Air (\%) & $6-8$ & 6,2 & 3,6 & 7.02 & 6.89 & 6.59 \\
Kadar Abu (\%) & $3-6$ & 8,3 & 5,9 & 6.27 & 6.27 & 6.20 \\
$\begin{array}{l}\text { Kadar Zat terbang } \\
\text { (\%) }\end{array}$ & $15-30$ & $19-28$ & 16,4 & 11.92 & 12.19 & 12.54 \\
$\begin{array}{l}\text { Kadar Karbon terikat } \\
(\%)\end{array}$ & $60-80$ & 60 & 75,3 & 80,89 & 80,52 & 80,33 \\
Nilai Kalor (kkal/kg) & $6000-$ & 6230 & 7289 & 7039.83 & 6982.63 & 6913.58 \\
& 7000 & & & & & \\
\hline
\end{tabular}

Sumber : Yunus (2015) dan Hasil Uji Lab Perpindahan Panas dan Massa UGM 
Berdasarkan komparasi dengan standar briket arang Jepang, Amerika dan Inggris, maka diperoleh hasil bahwa semua sampel untuk nilai kalor, kadar karbon terikat dan kadar zat terbang telah memenuhi standar briket Jepang, Amerika dan Inggris namun kadar air dan kadar abu masih belum memenuhi standar tersebut. Sampel A, B, C memenuhi standar untuk kadar abu untuk amerika saja, sedangkan kadar air hanya memenuhi untuk standar Jepang. Hal ini menunjukkan diperlukan treatment lagi untuk proses pirolisis pada suhu puncak dan total waktu proses yang lebih dari 1,5 jam.

\section{E. KESIMPULAN DAN SARAN \\ 1. Kesimpulan}

Berdasarkan hasil

penelitian tersebut dapat ditarik beberapa kesimpulan yakni :

1. Proses pirolisis menggunakan Retort Pirolisis Rocket Stove dapat mempirolisis briket arang limbah serbuk kayu dengan menghasilkan gas pirolisis mempan bakar yang dapat digunakan untuk pemanasan tanpa menghasilkan abu.

2. Karakteristik produk berupa briket arang menunjukkan nilai kalor antara 6913,58 $7039,83 \mathrm{kkal} / \mathrm{kg}$; kadar karbon terikat antara 80,33 - 80,89\%; kadar air antara 6,59 - 7,02\%; kadar zat terbang antara 11,92 - $12,54 \%$ dan kadar 6,20$6,27 \%$.
3. Terdapat kecenderungan pada pengaruh laju pemanasan pada proses dan produk dimana laju panas yang tinggi cenderung menghasilkan gas pirolisis yang lebih cepat dan briket arang serbuk kayu dengan nilai kalor, kadar karbon, kadar abu dan kadar air yang lebih rendah.

4. Keseluruhan sampel memenuhi standar briket arang Jepang, Amerika dan Inggris untuk nilai kalor, kadar karbon terikat, kadar zat terbang namun belum memenuhi untuk kadar abu dan kadar air.

\section{Saran}

Keseluruhan sampel
memenuhi standar briket
arang Jepang, Amerika dan
Inggris untuk nilai kalor,
kadar karbon terikat, kadar
zat terbang namun belum
memenuhi untuk kadar abu
dan kadar air. Untuk
memenuhi standar ekspor
diperlukan pengujian lagi
dengan variasi seperti suhu
puncak, laju pemanasan atau
lama proses pirolisis dengan
Rocket Stove

\section{F. DAFTAR PUSTAKA}

Aridito, M.N dan Cahyono, M.S. (2019). Pengaruh Laju Pemanasan dan Laju Hisap Gas Pirolisis dengan Sistem Tein Retort Rocket Stove Terhadap Karakteristik Proses dan Produk Briket Limbah Serbuk Kayu. Prosiding. Seminar 
Nasional Aplikasi Teknologi

Industri (SENIATI) 12

Februari 2019: Institut

Teknologi Nasional, Malang.

Basriyanta (2007). Pengaruh Jumlah

Campuran Ampas Jarak Pagar

Pada Proses Pembuatan Briket

Limbah Kayu Industri Mebel.

Thesis : Universitas Gadjah

Mada.

Mansyur, S dan Nurusman, H.A.,(2018) Analisis Pengaruh

Suhu dan Komposisi Briket Serbuk Kayu Terhadap

Karakteristik Briket Arang

Serbuk Kayu dengan Pirolisis

Single Retort Rocket Stove.

Jurnal Mekanika dan Sistem

Termal.

Moch. Yunus (2015). Karakteristik

Thermal Briket Limbah Serbuk

Kayu Sengon dengan Variasi

Tekanan. Skripsi. Universitas

Jember.

Patabang D, (2013) Karakteristik

Termal Briket Arang Serbuk

Gergaji Kayu Meranti . Jurnal

Mekanikal Vol. 4 No. 2 Juli 2013; 410-415.

Patandung, P dan Silabun P D

(2017).

Karakteristik

Penyalaan Briket Limbah

Serbuk Arang Tempurung

Kelapa dengan Bahan

Pemantik Abu Kelapa

(Cocodust). Jurnal Riset

Teknologi Industri Vol 11 No 1

Juni 2017.

Peraturan Menteri Energi dan

Sumberdaya Mineral No.12
Tahun $2017 \quad$ Tentang

Pemanfaatan Sumber Energi

Terbarukan untuk Penyediaan

Tenaga Listrik.

Peraturan Pemerintah Republik

Indonesia No.79 Tahun 2014

Tentang Kebijakan Energi

Nasional.

Undang-Undang Republik Indonesia Nomor 32 Tahun 2009 Tentang

Perlindungan dan Pengelolaan

Lingkungan Hidup.

Saputro D D, (2012) Karakteristik

Briket Limbah Pengolahan

Kayu Sengon dengan Metode

Cetak Panas. Prosiding

Seminar Nasional Aplikasi

Sains dan Teknologi (SNAST)

Periode III, Yogyakarta 3

November 2012.

Saleh A, Noviansti I, Murni S, Nurrahma, A (2017) Analisis

Kualitas Briket Serbuk Gergaji

Kayu dengan Penambahan

Tempurung Kelapa Sebagai

Bahan Bakar Alternatif. Jurnal

Al-Kimia Volume 5 Nomor 1

2017.

Wijayanti, D.S (2009). Karakteristik

Briket Arang dari Serbuk

Gergaji Kayu dengan

Penambahan Arang Cangkang

Kelapa Sawit. Skripsi.

Departemen Kehutanan

/Teknologi Hasil Hutan

Fakultas Pertanian Universitas

Sumatra Utara. 
